\title{
Synthesis and characterization of Trimethoprim metal complexes used as corrosion inhibitors for carbon steel in acid media
}

\author{
F.M. Ibrahim,* R.A.Hammza and D.H. Fadhil \\ Department of Chemistry, College of Science, Al-Nahrain University, Baghdad, Iraq \\ *E-mail: farahtaha2016@gmail.com
}

\begin{abstract}
Trimethoprim (TM) is an antibiotic used to treat bacterial infections as well as it is a heterocyclic compound, whose structure consists of 1,2,3-trimethoxybenzene and pyrimidine-2,4-diamine, therefore it can be used as a corrosion inhibitor due to easy production and low price on carbon steel in acidic media by adsorption process. $\mathrm{Cr}$ (III), $\mathrm{Mn}(\mathrm{II}), \mathrm{Co}(\mathrm{II}), \mathrm{Ni}(\mathrm{II})$ and $\mathrm{Cu}(\mathrm{II})$ complexes of Trimethoprim were synthesized and also used as a corrosion inhibitor. The Trimethoprim drug and its complexes were characterized by different spectroscopic methods: Ultraviolet-visible, Fourier transform infrared, conductivity measurements, thermal analysis (TG) and magnetic susceptibility measurement. Adsorption process can be attributed to changes in concentration of inhibitors with the acidity of a solution as well as the surface of the metal (carbon steel). The results of the experiment have shown the coordination of the Trimethoprim drug with the transition metal ions through nitrogen of pyrimidinyl ring so that square planar geometry was suggested for $\mathrm{Mn}$ (II), $\mathrm{Ni}$ (II), $\mathrm{Cu}$ (II) complexes while the $\mathrm{Cr}$ (III), $\mathrm{Co}$ (II) complexes have an octahedral geometry and these complexes have electrolyte properties. Corrosion inhibition on carbon steel was studied using weight loss method in one molar hydrochloric acid solution by organic inhibitor Trimethoprim and inorganic inhibitors (complexes) at different concentrations with different periods of time. The measurements have shown that Trimethoprim reduced the corrosion of the carbon steel surface and also the inhibition efficiency of the complexes increased with increasing concentration. The inhibition efficiency followed the order $\mathrm{Co}>\mathrm{Cu}>\mathrm{Cr}$ in one molar acidic solution.
\end{abstract}

Keywords: metal complexes of Trimethoprim, weight loss method, corrosion inhibitor.

Received: July 20, 2019. Published: September 19, 2019

doi: $\underline{10.17675 / 2305-6894-2019-8-3-20}$

\section{Introduction}

Drugs, polymers and plant extracts used as corrosion inhibitors form protective layers on carbon steel surfaces through adsorption process. Trimethoprim is an antibiotic used in the treatment of bladder infections and travelers' diarrhea and middle ear infections. Also, this pharmaceutical product is considered a highly effective system to inhibit the corrosion processes of steel in different media due to the presence of heteroatoms such as $\mathrm{N}$ and $\mathrm{O}$, 
that have high adsorption affinity. The adsorption of Trimethoprim compounds on the carbon steel surface is achieved by the interaction between lone electron pairs of heteroatoms and d-orbitals of the metal atoms [1-11]. The use of inorganic inhibitors due to the decomposing of organic compounds with temperature and time [12] for this reason the prepared complexes of TM used as inhibitors [13, 14]. Silver complexes of trimethoprim show stronger antibacterial activity compared to free drugs, these complexes characterized by spectroscopic and elemental analysis, the ligand coordinate through nitrogen of pyrimidine ring [15]. $\mathrm{Cu}, \mathrm{Zn}, \mathrm{Fe}$, Ti complexes of trimethoprim (TM) characterized by ${ }^{13} \mathrm{C}$ NMR, elemental analysis, electronic spectra and showed good antibacterial activity, the Ti-TM and $\mathrm{Cu}-\mathrm{TM}$ showed excellent anticancer activity [16]. $\mathrm{Cu}^{2+}, \mathrm{Zn}^{2+}, \mathrm{Pt}^{2+}, \mathrm{Ru}^{3+}$ and $\mathrm{Fe}^{3+}$ complexes of trimethoprim were prepared and characterized by spectroscopic and elemental analysis, morphology of metal complexes investigated by scanning electron microscopy. The biological activity of the trimethoprim complexes determined by binding to calf-thymus DNA (CT DNA) with UV spectroscopy and cyclic voltmeter, antimicrobial activity of these complexes and antifungal activity have been evaluated and compared with trimethoprim drug [17]. Inclusion complexes of trimethoprim with cyclodextrins in aqueous solution were prepared by several methods and characterized by many techniques and the antimicrobial activity of trimethoprim and the inclusion complexes were measured, the solubility of the drug increased by methyl- $\beta$ cyclodextrin and gave stable inclusion complexes [18]. $\mathrm{Mn}^{2+}, \mathrm{Fe}^{3+}, \mathrm{Co}^{2+}, \mathrm{Ni}^{2+}, \mathrm{Cu}^{2+}, \mathrm{Zn}^{2+}$, $\mathrm{Pb}^{2+}$ and $\mathrm{La}^{3+}$ complexes of trimethoprim derivative were prepared, determined by different physical and chemical techniques, the geometry of these complexes were proposed and the derivative act as a bidentate ligand [19]. Trimethoprim used as an inhibitor to prevent the corrosion of carbon steel in acidic environments. This study was done by weight loss and electrochemical measurements, at temperatures range $25-55^{\circ} \mathrm{C}$. The surface morphology of carbon steel before and after corrosion in $1.0 \mathrm{M} \mathrm{HCl}$ in the presence and absence of trimethoprim was measured by scanning electron microscopy. The inhibition efficiency, increased with inhibitor concentration increasing and decreased with increasing temperature [20]. Trimethoprim derivative synthesized and characterized by spectroscopic techniques, the corrosion inhibition behavior of this compound was studied by electrochemical measurements and gave good protection for the surface of the mild steel in aqueous $\mathrm{HCl}$. The quantum computations were determined for explanations the adsorption mode, the theoretical calculation conformed to the experimental results [21].

The aim of this work is to prepare $\mathrm{Cr}$ (III), $\mathrm{Mn}$ (II), $\mathrm{Co}$ (II), $\mathrm{Ni}$ (II) and $\mathrm{Cu}$ (II) complexes with Trimethoprim drug and characterize the structure of these complexes by spectroscopy and elemental analysis, then these complexes was used as inhibitors for carbon steel in acidic environment. The inhibition efficiency of this drug with their complexes was calculated according to the weight loss. 


\section{Experimental}

\section{Instrumentation}

Infrared spectra of (TM) complexes were measured by ALPHA FTIR spectrophotometer. The UV-Visible spectra of the complexes were measured using a Shimadzu UV-Vis 160A spectrophotometer. Thermal analyses (TG-DTG) were gained on a LINSEIS (STA PT1000). Johnson Mattey's magnetic susceptibility balance can be used for paramagnetic and diamagnetic materials. Molar conductivity measurements were carried by Corning conductivity meter 220 .

\section{Synthesis of drug complexes}

To $(2$ mole, $0.58 \mathrm{~g})$ of the trimethoprim drug in distilled water $(10 \mathrm{ml})$ slightly heat to dissolve completely a solution of metal ions ( 1 mole: $0.16 \mathrm{~g} \mathrm{CoCl}{ }_{2} \cdot 2 \mathrm{H}_{2} \mathrm{O}, 0.26 \mathrm{~g}$ $\left.\mathrm{NiSO}_{4} \cdot 6 \mathrm{H}_{2} \mathrm{O}, 0.25 \mathrm{~g} \mathrm{CuSO}_{4} \cdot 5 \mathrm{H}_{2} \mathrm{O}, 0.17 \mathrm{~g} \mathrm{MnSO}_{4} \cdot \mathrm{H}_{2} \mathrm{O}, 0.27 \mathrm{~g} \mathrm{CrCl}_{3} \cdot 6 \mathrm{H}_{2} \mathrm{O}\right)$ in distilled water $(10 \mathrm{ml})$ was mixed, then refluxed for 5 hours, filtered the solution and evaporate the solvent to give a colored precipitate then wash with distilled water and dried in oven at $50^{\circ} \mathrm{C}$.

\section{Corrosion part}

The purity of carbon steel alloy was $98.8 \% .1 \mathrm{M} \mathrm{HCl}$ was prepared by diluting the analytical grade, $37 \% \mathrm{HCl}$ in distilled water. The metal complexes of CrTM, CoTM and $\mathrm{CuTM}$ were being prepared according to the procedure above.

Inhibitor solutions with different concentrations from 100 to $500 \mathrm{ppm}$ were prepared by dissolving amount of the prepare TM and its metal complexes in $50 \mathrm{ml}$ of $1 \mathrm{M}$ hydrochloric acid and the blank solution was prepared as $50 \mathrm{ml}$ of $1 \mathrm{M} \mathrm{HCl}$ without inhibitor. Carbon steel specimens are cleaned by different grade emery papers and degreased with acetone. An analytical balance was used to measure the initial weight of each specimen and then the specimens were immersed in $1 \mathrm{M} \mathrm{HCl}$ solution with different concentrations of the inhibitor and without inhibitor in a different time at room temperature. Finally the specimens were washed and weighed.

\section{Result and discussion}

\section{Infrared spectra of complexes}

The drug has two donor nitrogen of pyrimidinyl ring appear at $\left(3465.61 \mathrm{~cm}^{-1}, 3315.01 \mathrm{~cm}^{-1}\right)$ for $v_{\text {as }} \mathrm{NH}_{2}$ and $v_{s} \mathrm{NH}_{2}$, respectively, these two bands shifted significantly in the spectra of complexes and appear in the region (3402.0-3312.09 $\mathrm{cm}^{-1}$ ) assigned to coordinate with metal ions.

Bands at $\left(2930.24,2830.61,1459.31,1329.99 \mathrm{~cm}^{-1}\right)$ for $v_{\text {as }} \mathrm{CH}_{3}, v_{\mathrm{s}} \mathrm{CH}_{3}, \delta_{\mathrm{as}} \mathrm{CH}_{3}$ and $\delta_{\mathrm{s}} \mathrm{CH}_{3}$, respectively. Bands at $1630.65 \mathrm{~cm}^{-1}, 1589.88 \mathrm{~cm}^{-1}$ can be assigned to $\mathrm{C}=\mathrm{N}, \mathrm{C}=\mathrm{C}$ stretching frequencies [22, 23], see Table 1, Figures 1-2. 


\section{Ultraviolet-Visible spectroscopy}

The drug show band at $295 \mathrm{~nm}$ due to $n \rightarrow \pi^{*}$ transition while the spectra of complexes showed bands at region (227-382) $\mathrm{nm}$ which are characteristic for charge transition and ligand field transition. The CrTM complex showed bands at $21739 \mathrm{~cm}^{-1},{ }^{4} \mathrm{~A}_{2} \mathrm{~g}(\mathrm{~F}) \rightarrow{ }^{4} \mathrm{~T}_{2} \mathrm{~g}$ (F) and ligand field transitions. CoTM complex has bands at $17391 \mathrm{~cm}^{-1}, 16000 \mathrm{~cm}^{-1}$, $15243 \mathrm{~cm}^{-1}$ for ${ }^{4} \mathrm{~T}_{1} \mathrm{~g}(\mathrm{~F}) \rightarrow{ }^{4} \mathrm{~T}_{1} \mathrm{~g}(\mathrm{P}),{ }^{4} \mathrm{~T}_{1} \mathrm{~g}(\mathrm{~F}) \rightarrow{ }^{4} \mathrm{~A}_{2} \mathrm{~g}(\mathrm{~F}),{ }^{4} \mathrm{~T}_{1} \mathrm{~g}(\mathrm{~F}) \rightarrow{ }^{4} \mathrm{~T}_{2} \mathrm{~g}(\mathrm{~F})$ transitions, respectively, so the geometry of $\mathrm{Co}$ (II) and $\mathrm{Cr}$ (III) expected octahedral. NiTM complex has a characteristic band at $23809 \mathrm{~cm}^{-1}$ for ${ }^{1} \mathrm{~A}_{1} \mathrm{~g} \rightarrow{ }^{1} \mathrm{~A}_{2} \mathrm{~g}$ transition. CuTM complex showed bands at $15847.86 \mathrm{~cm}^{-1}$ and $15600.62 \mathrm{~cm}^{-1}$ for ${ }^{2} \mathrm{~B}_{1} \mathrm{~g} \rightarrow{ }^{2} \mathrm{~A}_{1} \mathrm{~g},{ }^{2} \mathrm{~B}_{1} \mathrm{~g} \rightarrow{ }^{2} \mathrm{Eg}$ transitions so that square planar geometry suggested for $\mathrm{Cu}^{2+}$ and $\mathrm{Ni}^{2+}$ complexes, see Table 1 [6, 23-24].

Table 1. Some characteristic of IR and UV-Vis. Bands of TM and its complexes.

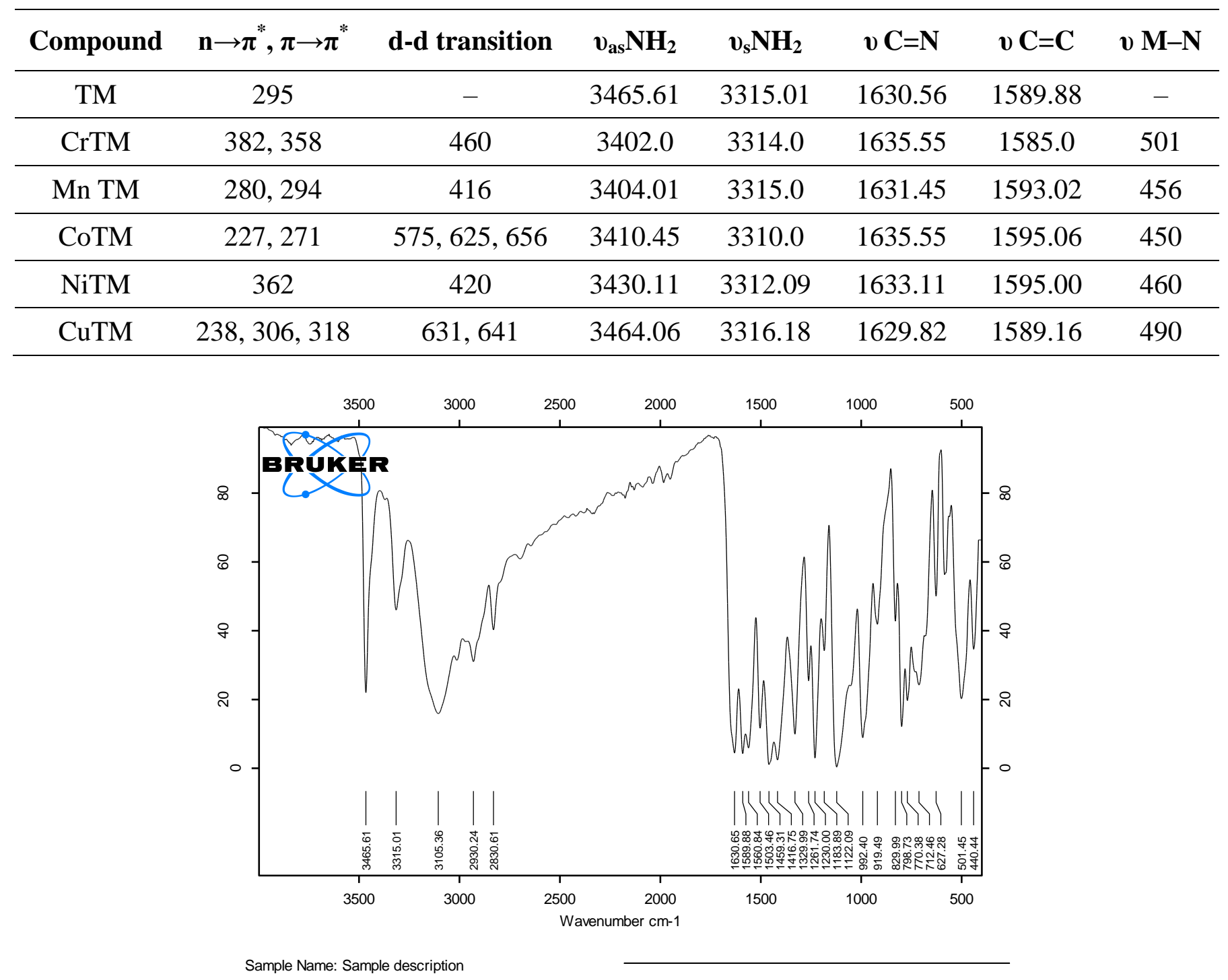

Figure 1. IR spectrum of TM. 


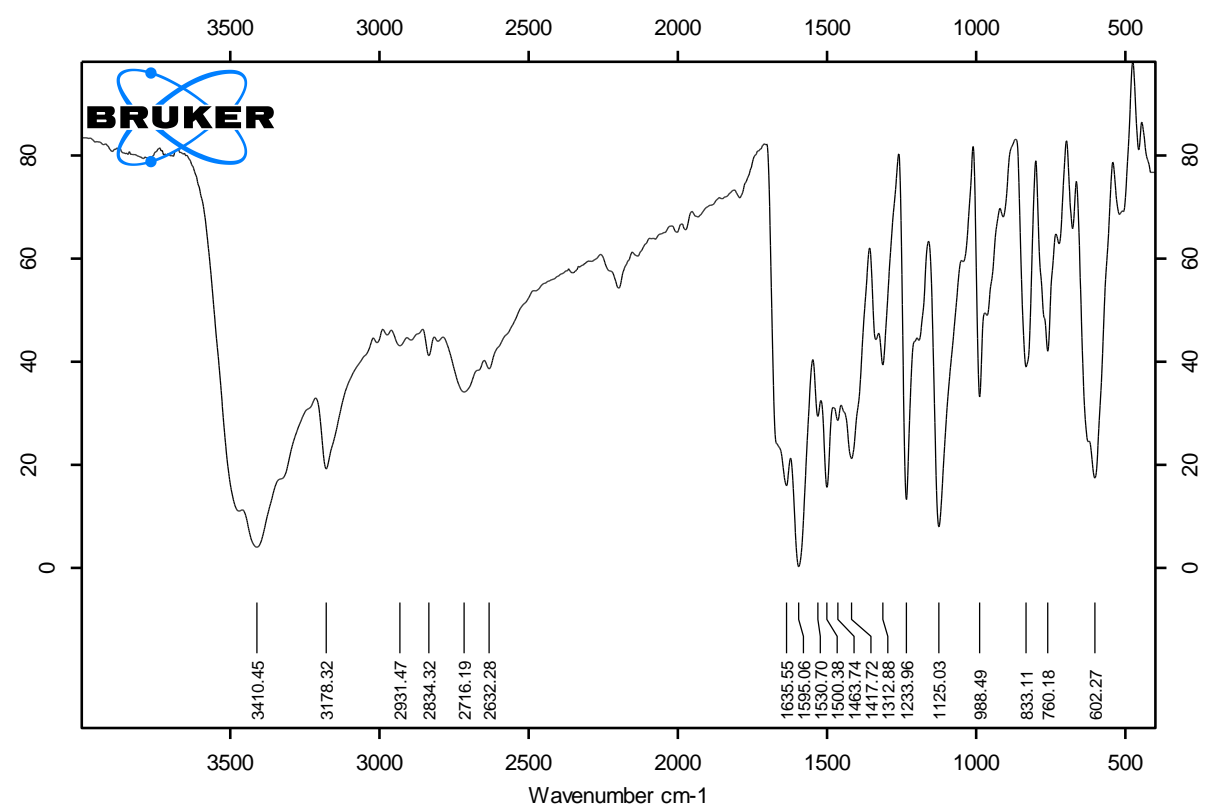

Sample Name: Sample description

Figure 2. IR spectrum of CoTM.

Table 2. Some physical analysis of TM complexes

\begin{tabular}{ccccc}
\hline Complex & Molecular formal & Color & $\boldsymbol{\mu}_{\text {eff. }}$ & $\begin{array}{c}\text { Conductivity, } \\
\text { DMF solvent }(\boldsymbol{\mu s})\end{array}$ \\
\hline $\mathrm{TM}$ & $\mathrm{C}_{14} \mathrm{H}_{18} \mathrm{~N}_{4} \mathrm{O}_{3}$ & White & - & - \\
\hline $\mathrm{CrTM}$ & {$\left[\mathrm{CrL}_{2}\left(\mathrm{H}_{2} \mathrm{O}\right)_{2}\right] \mathrm{Cl}_{3}$} & Dark green & 3.8 & 210 \\
\hline $\mathrm{MnTM}$ & {$\left[\mathrm{MnL}_{2}\right] \mathrm{SO}_{4}$} & Light brown & 5.3 & 70 \\
\hline $\mathrm{CoTM}$ & {$\left[\mathrm{CoL}_{2}\left(\mathrm{H}_{2} \mathrm{O}_{2}\right] \mathrm{Cl}_{2}\right.$} & Dark pink & 4.6 & 135 \\
\hline $\mathrm{NiTM}$ & {$\left[\mathrm{NiL}_{2}\right] \mathrm{SO}_{4}$} & Green & 0 & 66 \\
\hline $\mathrm{CuTM}$ & {$\left[\mathrm{CuL}_{2}\right] \mathrm{SO}_{4}$} & Light green & 1.9 & 89 \\
\hline
\end{tabular}

Thermal analysis of metal complexes

Table 3. Thermo analysis of some TM complexes.

\begin{tabular}{cccc}
\hline Complex & Temperature rang, ${ }^{\circ} \mathbf{C}$ & $\begin{array}{c}\text { Weight loss, found } \\
\text { (calc.) }\end{array}$ & Elimination part \\
\hline$\left[\mathrm{CrL}_{2}\left(\mathrm{H}_{2} \mathrm{O}\right)_{2}\right] \mathrm{Cl}_{3}$ & $66-130$ & $19.12(18.82)$ & $-2 \mathrm{H}_{2} \mathrm{O},-3 \mathrm{Cl}$ \\
& $330-570$ & $68.89(69.27)$ & $-\mathrm{C}_{18} \mathrm{H}_{22} \mathrm{O}_{6}$ \\
& & & $-4 \mathrm{H}_{2}$ \\
& & & $-\mathrm{C}_{10} \mathrm{H}_{6} \mathrm{~N}_{4}$ \\
\hline
\end{tabular}




\begin{tabular}{cccc}
\hline$\left[\mathrm{MnL}_{2}\right] \mathrm{SO}_{4}$ & $130-320$ & $56.00(54.97)$ & $-\mathrm{C}_{18} \mathrm{H}_{22} \mathrm{O}_{6},-\mathrm{SO}_{3}$ \\
& $390-560$ & $25.11(28.89)$ & $-\mathrm{C}_{10} \mathrm{H}_{14} \mathrm{~N}_{4} \mathrm{O}$ \\
\hline$\left[\mathrm{CoL}_{2}\left(\mathrm{H}_{2} \mathrm{O}\right)_{2}\right] \mathrm{Cl}_{2}$ & $55-140$ & $15.32(14.68)$ & $-2 \mathrm{H}_{2} \mathrm{O},-2 \mathrm{Cl}$ \\
& $230-500$ & $74.02(75.83)$ & $-\mathrm{C}_{18} \mathrm{H}_{30} \mathrm{O}_{6}$ \\
& & & $-\mathrm{C}_{10} \mathrm{H}_{6} \mathrm{~N}_{6}$ \\
\hline$\left[\mathrm{NiL}_{2}\right] \mathrm{SO}_{4}$ & $210-288$ & $45.89(46.60)$ & $-\mathrm{C}_{18} \mathrm{H}_{22} \mathrm{O}_{6}$, \\
& $330-490$ & $38.10(39.90)$ & $-\mathrm{C}_{10} \mathrm{H}_{14} \mathrm{~N}_{4} \mathrm{O},-\mathrm{SO}_{3}$ \\
\hline \multirow{2}{*}[\mathrm{CuL}_{2}]{$\mathrm{SO}_{4}$} & $279-340$ & $44.89(46.28)$ & $-\mathrm{C}_{18} \mathrm{H}_{22} \mathrm{O}_{6}$ \\
& $380-500$ & $38.00(39.62)$ & $-\mathrm{SO}_{3},-\mathrm{C}_{10} \mathrm{H}_{14} \mathrm{~N}_{4} \mathrm{O}$ \\
\hline
\end{tabular}

The thermo-gravimetric technique help to investigate the structure of complexes, $\left[\mathrm{MnC}_{28} \mathrm{H}_{36} \mathrm{~N}_{8} \mathrm{O}_{10} \mathrm{~S}\right.$ ] complex decomposes between $130-320^{\circ} \mathrm{C}$ to form [ $\mathrm{MnC}_{10} \mathrm{H}_{14} \mathrm{~N}_{8} \mathrm{O}$ ] due to to the elimination part $\left(\mathrm{C}_{18} \mathrm{H}_{22} \mathrm{O}_{6}, \mathrm{SO}_{3}\right)$ and the second loss is $\left(\mathrm{C}_{10} \mathrm{H}_{14} \mathrm{~N}_{4} \mathrm{O}\right)$ between $390-560^{\circ} \mathrm{C}$ to residue $\left[\mathrm{MnN}_{4}\right] .\left[\mathrm{NiC}_{28} \mathrm{H}_{36} \mathrm{~N}_{8} \mathrm{O}_{10} \mathrm{~S}\right]$ complex is assigned to the elimination of $\left(\mathrm{C}_{18} \mathrm{H}_{22} \mathrm{O}_{6}\right)$, the other loss of $\left[\mathrm{NiC}_{10} \mathrm{H}_{14} \mathrm{~N}_{8} \mathrm{O}_{4} \mathrm{~S}\right]$ between $330-490^{\circ} \mathrm{C}$ to remain [ $\left.\mathrm{NiN}_{4}\right]$. The first loss of $\left[\mathrm{CuC}_{28} \mathrm{H}_{36} \mathrm{~N}_{8} \mathrm{O}_{10} \mathrm{~S}\right]$ gave $\left[\mathrm{CuC}_{10} \mathrm{H}_{14} \mathrm{~N}_{8} \mathrm{O}_{4} \mathrm{~S}\right]$ at $279-340^{\circ} \mathrm{C}$, the other loss at $380-500^{\circ} \mathrm{C}$ for elimination $\left(\mathrm{SO}_{3}, \mathrm{C}_{10} \mathrm{H}_{14} \mathrm{~N}_{4} \mathrm{O}\right)$ and remain $\left[\mathrm{CuN}_{4}\right]$. CrTM and CoTM complexes shows the loss in weight corresponding to water molecules and the remain was $\left[\mathrm{CrN}_{4}\right]$ and $\left[\mathrm{CoN}_{2}\right]$, respectively, shown Table 3.

\section{Weight loss measurements}

The corrosion rate $(C R)$ has been estimated from this equation, $C R=\left(m_{1}-m_{2}\right) / S \cdot t,\left(m_{1}\right)$ and $\left(m_{2}\right)$ are masses of the specimen before and after corrosion respectively, $S$ area of the specimen, $t$ corrosion time. The alloy will be removed and cleaned after each immersion time, then dry and reweight to obtain weight loss. Inhibition efficiency (PE, \%) was obtained by using the following equation:

$$
P E, \%=\left(1-C R / C R^{0}\right) \cdot 100
$$

$C R$ and $C R^{0}$ are the corrosion rate $\left(\mathrm{mg} / \mathrm{cm}^{2} / \mathrm{h}\right)$ of carbon steel specimen with and without inhibitors, respectively. $\left(1-C R / C R^{0}\right)$ was used to determine the degree of surface coverage $(\theta)$. Results showed the inhibitor efficiency $(P E, \%)$ increased when the concentration of inhibitor increased, the $(P E, \%),(C R)$ and $(\theta)$ for CrTM, CoTM and CuTM complexes at different concentrations and different periods of time.

From the data of the experiment the $\mathrm{Cr}(\mathrm{III}), \mathrm{Co}(\mathrm{II})$ and $\mathrm{Cu}(\mathrm{II})$ complexes inhibit the corrosion of carbon steel alloy at all concentrations was used in our work. The inhibitor efficiency $(P E, \%)$ for these complexes, drug increases with increase their concentration, as shown in Figure 3 in $1 \mathrm{M} \mathrm{HCl}$ solution. 


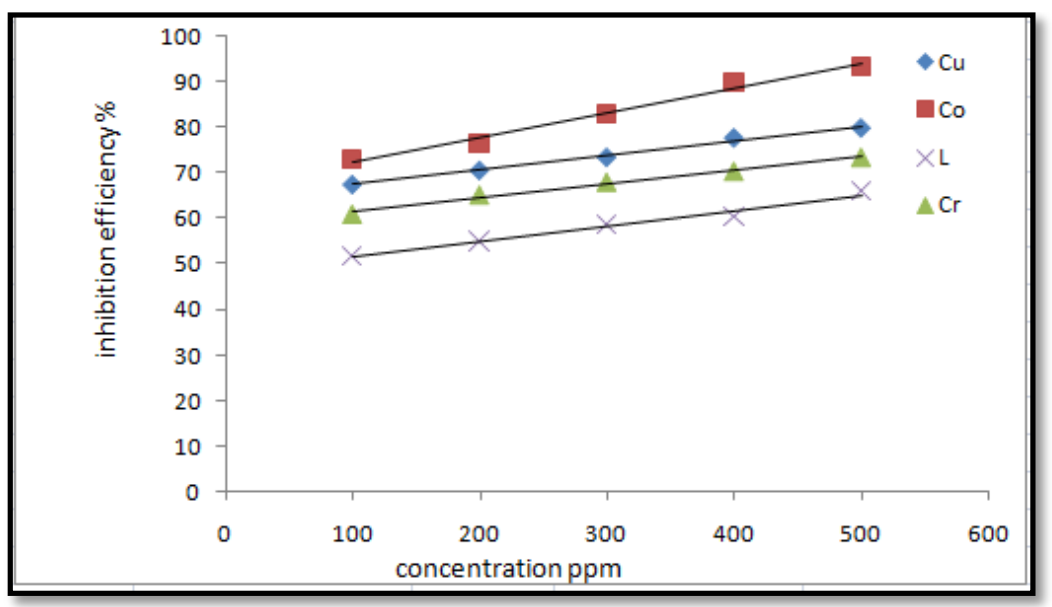

Figure 3. The \% PE against concentration of metal complexes and TM on carbon steel at 3 hours.

From the above results the geometry of complexes was suggested octahedral conformation for $\mathrm{Co}$ (II) with $\mathrm{Cr}$ (III) and square planar conformation for $\mathrm{Mn}$ (II), $\mathrm{Ni}$ (II) and $\mathrm{Cu}(\mathrm{II})$, shown in Figures 4 and 5.

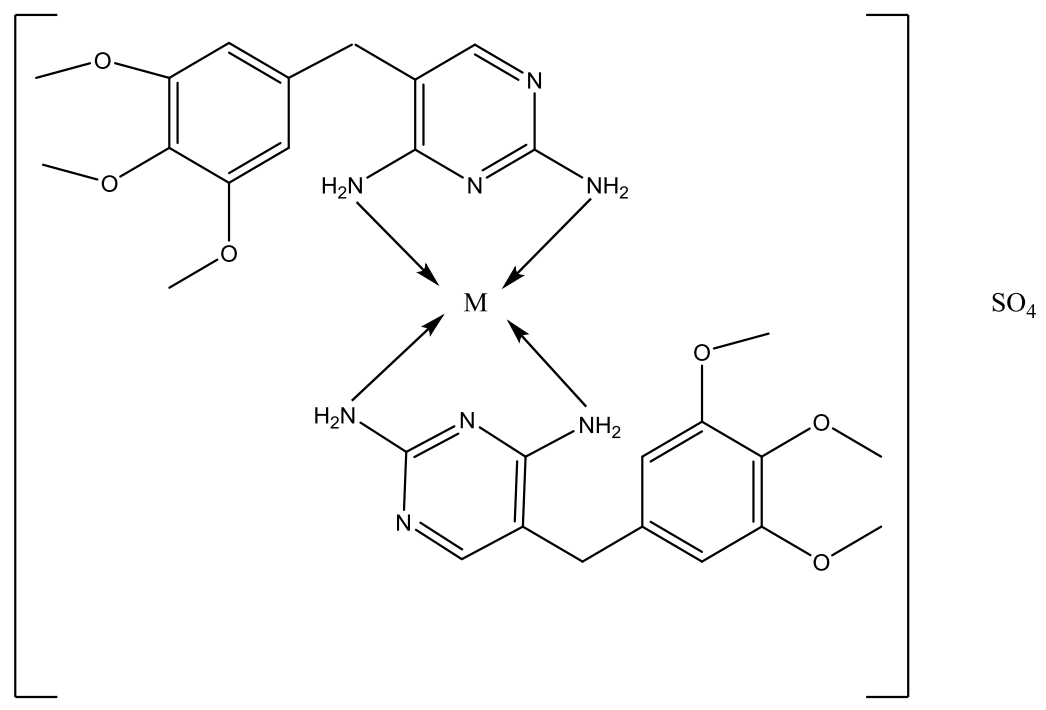

$\mathrm{M}: \mathrm{Ni}(\mathrm{II}), \mathrm{Cu}(\mathrm{II}) \mathrm{Mn}(\mathrm{II})$

Figure 4. Square planar geometry for $\mathrm{Mn}(\mathrm{II}), \mathrm{Ni}(\mathrm{II})$ and $\mathrm{Cu}(\mathrm{II})$ complexes. 


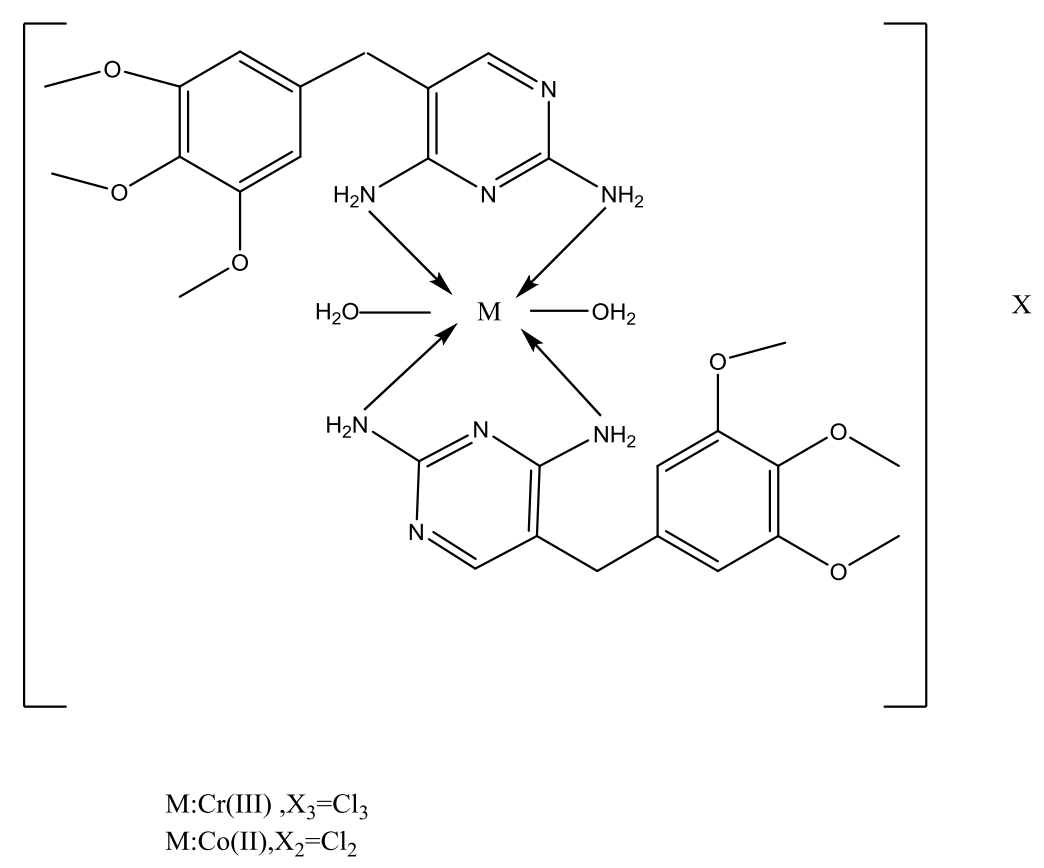

Figure 5. Octahedral geometry for $\mathrm{Co}$ (II) with $\mathrm{Cr}$ (III) complexes.

\section{Conclusion}

Complexes of TM were synthesized and characterized. The molar conductivity of these complexes has electrolyte nature. The $\mathrm{Ni}(\mathrm{II})$ complex has diamagnetic properties. Octahedral conformation has been suggested for $\mathrm{Co}$ (II) with $\mathrm{Cr}$ (III) complexes and square planar conformation for $\mathrm{Mn}(\mathrm{II}), \mathrm{Ni}(\mathrm{II})$ and $\mathrm{Cu}(\mathrm{II})$ complexes. The inhibition efficiency increases with increase in the concentration of CoTM $>\mathrm{CuTM}>\mathrm{CrTM}$ complexes.

\section{Acknowledgments}

The authors acknowledge the Department of Chemistry, College of Science, Al-Nahrain University.

\section{Reference}

1. F. Von Nussbaum, M. Brands, B. Hinzen, S.W. Weigand and D. Habich, Medicinal Chemistry of Antibacterial Natural Products - Exodus or Revival, Angew. Chem., Int. Ed., 2006, 45, no. 31, 5072-5129. doi: 10.1002/anie.200600350

2. A. Samide and B. Tutunaru, Quinine sulfate: a pharmaceutical product as effective corrosion inhibitor for carbon steel in hydrochloric acid solution, Cent. Eur. J. Chem., 2014, 12, no. 9, 901-908. doi: 10.2478/s11532-013-0399-9

3. R. Sagar, S. Suryakant, Sh. Asadulla and K. Gajanan, Understanding the Corrosion Inhibition by Rodine Spl 213 on Mild Steel Surface in $\mathrm{HCl}$ Acid under Different Conditions, Int. J. Innov. Res. Sci., Eng. Technol., 2017, 6, no. 3, 3481-3489. 
4. N.K. Gupta, C.S.A. Gopal, V. Srivastava and M.A. Quraishi, Application of expired drugs in corrosion inhibition of mild steel, Int. J. Pharm. Chem. Anal., 2017, 4, 8-12.

5. G. Zhu, J. Hou, H. Zhu, R. Qiu and J. Xu, Electrochemical synthesis of poly $(3,4-$ ethylenedioxythiophene) on stainless steel and its corrosion inhibition performance, $J$. Coat. Technol. Res., 2013, 10, 659-668. doi: 10.1007/s11998-013-9482-6

6. L.M.P. Dolabella, J.G. Oliveira, V. Lins, T. Matencio and W.L. Vasconcelos, Ethanol extract of propolis as a protective coating for mild steel in chloride media, J. Coat. Technol. Res., 2016, 13, 543-555. doi: 10.1007/s11998-015-9765-1

7. P. Geethamani and P.K. Kasthuri, Adsorption and corrosion inhibition of mild steel in acidic media by expired pharmaceutical drug, Cogent Chem., 2015, 1, no. 1091558, 111. doi: $10.1080 / 23312009.2015 .1091558$

8. M.J. Palimi, M. Rostami, M. Mahdavian and B. Ramezanzadeh, A study on the corrosion inhibition properties of silane-modified $\mathrm{Fe}_{2} \mathrm{O}_{3}$ nanoparticle on mild steel and its effect on the anticorrosion properties of the polyurethane coating, J. Coat. Technol. Res., 2015, 12, 277-292. doi: 10.1007/s11998-014-9631-6

9. L. Guo, I.B. Obot, X. Zheng, X. Shen, Y. Qiang, S. Kaya and C. Kaya, Theoretical insight into an empirical rule about organic corrosion inhibitors containing nitrogen, oxygen, and sulfur atoms, Appl. Surf. Sci., 2017, 406, 301-306. doi: 10.1016/j.apsusc.2017.02.134

10. T. Ramdé, S. Rossi and L. Bonou, Corrosion Inhibition Action of Sulfamethoxazole for Brass in Acidic Media, Int. J. Electrochem. Sci., 2016, 11, 6819-6829. doi: $10.20964 / 2016.08 .39$

11. A.S. Fouda, F.I. El-Dossoki, W.T. Elbehairy and A. Elmohamady, Flubendazole: New Corrosion Inhibitor for 6061 Al-Si Alloy in 0.1M HCl Medium, Int. J. Electrochem. Sci., 2018, 13, 10973-10989. doi: 10.20964/2018.11.95

12. M.M. Antonijevic and M.B. Petrovic, Copper Corrosion Inhibitors. A review, Int. J. Electrochem. Sci., 2008, 3, 1-28.

13. S.S. Abd El Rehim, M.A. Ibrahim and M.K.F. Khalid, 4-amino antipyrine as an inhibitor of mild steel corrosion in $\mathrm{HCl}$ solution, J. Appl. Electrochem., 1999, 29, $593-$ 599. doi: 10.1023/A:1003450818083

14. K. Nageh Allam, Corrosion Protection on Copper by Imidazole and Its Derivatives, Appl. Surf. Sci., 2010, 253, 4570.

15. O.G. Idemudia, P.A. Ajibade and A.I. Okoh, Synthesis, characterization and antibacterial screeningof 2,4-diaminopyrimidine pyrimethamine and trimethoprim silver complexes, Afr. J. Biotechnol., 2012, 11, no. 39, 9323-9329.

16. A. El-Shekeil, A. Omer, S. Al-Aghbari and O. Al-Shuja'a, Anti-Cancer and AntiMicrobial Activity Studies of Some Complexes of Trimethoprim, J. Cancer Res. Updates, 2013, 2, no. 1, 14-20. 
17. N. Demirezen, D. Tarınç, D. Polat, M. Ceşme, A. Gölcü and M. Tümer, Synthesis of trimethoprim metal complexes: Spectral, electrochemical, thermal, DNA-binding and surface morphology studies, Spectrochim. Acta, Part A, 2012, 94, 243-55. doi: 10.1016/j.saa.2012.03.055

18. A. Figueiras, O. Cardoso, F. Veiga, R. BF de Carvalho and G. Ballaro, Preparation and characterization of Trimethoprim inclusion complex with Methyl- $\beta$-Cyclodextrin and determination of its antimicrobial activity, Pharm. Anal. Acta, 2015, 6, no. 8, 1-5. doi: $\underline{10.4172 / 2153-2435.1000405}$

19. A.M.A. Alaghaz, R.S. Farag, M.A. Elnawawy and A.D.A. Ekaw, Synthesis and Spectral Characterization Studies of New Trimethoprim-Diphenylphosphate Metal Complexes, Int. J. Sci. Res. (IJSR), 2016, 5, no. 1, 1220-1229.

20. A. Samide, A pharmaceutical product as corrosion inhibitor for carbon steel in acidic environments, J. Environ. Sci. Health, Part A: Toxic/Hazard. Subst. Environ. Eng., 2013, 48, no. 2, 159-165. doi: 10.1080/03601234.2012.716744

21. E.E. Elemike, H.U. Nwankwo, D.C. Onwudiwe and E.C. Hosten, Synthesis, structures, spectral properties and DFT quantum chemical calculations of (E)-4-(((4propylphenyl)imino)methyl)phenol and (E)-4-((2-tolylimino)methyl)phenol; their corrosion inhibition studies of mild steel in aqueous HCl, J. Mol. Struct., 2017, 1141, 12-22. doi: 10.1016/j.molstruc.2017.03.071

22. R.M. Silverstein, F.X. Webster, D.J. Kiemle and D.L. Bryce, Spectrometric Identification of Organic Compounds, 8th edition, John Wiely and Sons Inc., United states of America, 2015.

23. A. Lawal, P.A. Ayanwale, J.A. Obaleye, A.O. Rajee, H.F. Babamale and M. Lawal, Synthesis, Characterization and Biological Studies of Mixed Ligands NicotinamideTrimethoprim Complexes, Int. J. Chem., Mater. Environ. Res., 2017, 4, no. 1, 97-10.

24. A.S. Stella Shalini, M. Amaladasan, N. Prasannabalaji, J. Revathi and G. Muralitharan, Synthesis, characterization and antimicrobial studies on 13-membered-N6-macrocyclic transition metal complexes containing trimethoprim, Arabian J. Chem., 2014. doi: $\underline{10.1016 / j . a r a b j c .2014 .11 .033}$ 